\title{
Peran Rektor Dalam Program Zero Waste di Lingkungan Kampus di Kota Mataram
}

\author{
Siti Hasanah ${ }^{1}$
}

${ }^{1}$ Departemen Ilmu Hukum, Universitas Muhammadiyah Mataram, magaparang1@gmail.com

\begin{tabular}{l} 
INFO ARTIKEL \\
\hline Riwayat Artikel: \\
Diterima: 18 September \\
2020 \\
Disetujui: 30 September \\
2020
\end{tabular}

\section{Kata Kunci:}

Peran Rektor

Zero Waste

Lingkungan kampus

Instrumen Yuridis

\begin{abstract}
ABSTRAK
Abstrak: Masalah sampah di Indonesia sangat kompleks, kondisi ini sebagai imbas prilaku masyarakat yang tidak sportif dalam membuang sampah. Insportifitas tersebut juga terjadi dalam lingkungan kampus, terbawa oleh civitas akademika sehingga lingkungan kampuspun tidak luput dari masalah sampah. Himbauan dan sosialisasi termasuk ketersediaan sarana dan prasarana penunjang yang belum terstandar, belum berhasil merubah prilaku civitas akademika untuk sportif membuang sampah dilingkungan kampus. Penelitian ini bertujuan untuk memaksimalkan peran rektor dalam program zero waste yang dimplementasikan melalui pengadaan instrumen yuridis berupa peraturan rektor atau surat keputusan rektor, atau surat edaran rektor tentang sistem pengelolaan dan penanggulangan sampah di lingkungan kampus dalam rangka memutus mata rantai prilaku civitas akademika yang tidak sportif membuang sampah. Jenis penelitian yang digunakan adalah yuridis empiris dengan pendekatan sosiologis hukum. Metode pengumpulan data menggunakan wawancara, pengamatan dan dokumentasi. Hasil penelitian: 1) Peran rektor belum maksimal dalam program zero waste dilingkungan kampus di kota Mataram. 2) Tidak tersedianya instrumen yuridis sistem pengelolaan dan penanggulangan sampah di lingkungan kampus dan tidak tersedianya sarana dan prasarana penunjang yang sesuai standar Keputusan Menteri Kesehatan Republik Indonesia Nomor 1405/MENKES/SK/XI/2002 tentang standar syarat kesehatan Lingkungan Kerja Perkantoran dan Industri.
\end{abstract}

\begin{abstract}
The problem of waste in Indonesia is very complex, this condition is the result of unsportsmanlike behavior of society in disposing of garbage. This encouragement also occurs in the campus environment, carried by the academic community so that the campus environment is not free from waste problems. Appeals and socialization, including the availability of supporting facilities and infrastructure that are not standardized, have not succeeded in changing the behavior of the academic community to be sporty in disposing of garbage in the campus environment. This study aims to maximize the role of the chancellor in the zero waste program which is implemented through the procurement of juridical instruments in the form of a rector's regulation or a rector's decree, or a rector's circular on waste management and management systems in the campus environment in order to break the chain of unsportsmanlike behavior of the academic community. trash. The type of research used is juridical empirical with a sociological legal approach. Methods of data collection using interviews, observation and documentation. Research results: 1) The role of the rector has not been maximal in the zero waste program in the campus environment in the city of Mataram. 2) Unavailability of juridical instruments for waste management and control systems in the campus environment and the unavailability of supporting facilities and infrastructure in accordance with the standards of the Decree of the Minister of Health of the Republic of Indonesia Number 1405 / MENKES / SK / XI / 2002 concerning standard health requirements for Office and Industrial Work Environment.
\end{abstract}

\section{A. LATAR BELAKANG}

Indonesia menduduki urutan kedua sebagai negara dengan sampah plastik terbanyak di lautan. Posisi Indonesia hanya berselang satu peringkat dengan Tiongkok. Kondisi sampah plastik di lautan Indonesia sudah begitu mengkhawatirkan karena mempengaruhi sejumlah kawasan wisata yang menjual keindahan laut seperti Pulau Seribu dan Bunaken. "Jumlah sampah plastik yang sudah begitu besar jumlahnya sudah menyebar ke daerah-daerah wisata sehingga kita mengalami kerugian karena turis tidak akan datang.

Penelitian ini memiliki obyek kajian yang sama dengan penelitian yang pernah dilakukan oleh Ika Wahyuning Widiarti Program Studi Teknik Lingkungan Fakultas Teknologi Mineral Universitas Pembangunan "Veteran" Yogyakarta Tahun 2012 dengan Tema "Pengelolaan Sampah Berbasis "Zero Waste" Skala Rumah Tangga Secara Mandiri.[1] Lainnya menemukan bahwa komposisi timbulan sampah yang dihasilkan 
kampus Universitas Semarang terdiri dari sampah organik (65,24\%), sampah kertas (10,56\%), sampah plastik (23,77\%) dan sampah lainnya sebanyak (0,43\%).[2] Pelatihan terbentuknya komitmen bersama untuk mewujudkan zero waste kampus UMMat.[3] Zero Waste?[4] upaya mengatasi masalah pengelolaan sampah belum maksimal dan kurangnya kesadaran masyarakat.[5] beberapa penelitian sebelumnya lebih focus pada pengelolaan sampah berbasis zero waste, dampak pembungan sampak di kampus, mengatasi masalah zero waste dan kampanye zero waste.

Semantara yang menjadi pembeda antara penelitian ini dengan penelitian sebelumnya adalah terkait ruang lingkup kajian. Dalam penelitian sebelumnya ruang lingkup kajian difokuskan pada penemuan alternatif untuk mengelola sampah anorganik berbasis nilai ekonomis, dan penemuan indikator berpengaruh dalam tercapainya pelaksanaan pengelolaan sampah berbasis zero waste secara mandiri, sedangkan dalam penelitian ini obyek kajian difokuskan untuk melihat perbandingan antara: 1) kondisi kebersihan lingkungan kampus yang telah memiliki dan yang belum memiliki instrumen yuridis berupa peraturan rektor atau surat keputusan rektor, atau surat edaran rektor tentang pengelolaan dan penanggulangan sampah di lingkungan kampus. 2) kondisi kebersihan lingkungan kampus yang telah memiliki dan yang belum memiliki sarana dan prasaran penunjang sesuai Keputusan Menteri Kesehatan Republik Indonesia Nomor 1405/MENKES/SK/XI/2002 tentang syarat kesehatan Lingkungan Kerja Perkantoran dan Industri. Kondisi kebersihan tersebut menjadi barometer untuk menentukan maksimal atau tidaknya peran rektor dalam program zero waste dilingkungan kampus dimasing masing perguruan tinggi (universitas) di Kota Mataram.

Problem sampah dan dampaknya juga dirasakan oleh Provinsi Nusa Tenggara Barat sebagai wilayah destinasi wisata halal yang sudah mendunia. Produksi sampah di NTB mencapai 3.500 ton per hari. Dari ribuan ton tersebut hanya 18 persen saja yang dibuang ke tempat pembuangan akhir (TPA) dan sisanya masih dibuang sembarangan oleh masyarakat. Hal itu dikatakan Kepala Dinas Kehutanan dan Lingkungan Hidup Provinsi NTB, Madani Mukarom kepada Global FM Lombok Senin (17/12) di Mataram. Sebagai gambaran volume sampah yang dihasilkan setiap harinya di Kota Mataram sebesar 1126 m3 yang bersumber dari : Sampah Pemukiman: $425 \mathrm{~m} 3 / \mathrm{hr}$, Sampah Pasar : 380 m3/hr, Sampah Komersial : 108 $\mathrm{m} 3 / \mathrm{hr}$, Sampah Perkantoran : $36 \mathrm{~m} 3 / \mathrm{hr}$, Fasilitas Umum : $60 \mathrm{~m} 3 / \mathrm{hr}$, Penyapuan Jalan : $34 \mathrm{~m} 3 / \mathrm{hr}$, Kawasan Industri :18 m3/hr, Saluran : $11 \mathrm{~m} 3 / \mathrm{hr}$, Lainlain : $54 \mathrm{~m} 3 / \mathrm{hr}$, Jumlah : $1126 \mathrm{~m} 3 / \mathrm{hr}$. Jumlah sampah yang dihasilkan oleh kota Mataram dalam sehari mencapai 1.300 meter kubik. Pertambahan penduduk dan tingginya produksi sampah masyarakat menambah rumitnya mengurai masalah sampah khususnya diwilayah Kota Mataram.

Masalah krusial sampah secara nasional dan lokal merupakan imbas dari prilaku masyarakat yang tidak sportif dalam hal membuang sampah. Kondisi ini juga terjadi dalam lingkungan kampus. Himbauan dan sosialisasi telah diupayakan melalui berbagai strategi pemasangan stiker, pamflet, penyediaan tempat sampah yang belum terstandar sesuai Keputusan Menteri Kesehatan Republik Indonesia Nomor 1405/MENKES/SK/XI/2002 tentang standar syarat kesehatan Lingkungan Kerja Perkantoran dan Industri belum berhasil menertibkan prilaku civitas akademika dalam menjaga kebersihan lingkungan. Prilaku bawaan secara personal dari lingkungan sosial asal civitas akademika memang sulit untuk dirubah. Perlu langkah strategis untuk memutus siklus mata rantai dan prilaku tersebut.

Tujuan dalam artikel ini menjelaskan dua hal penting yaitu 1) perbandingan kebersihan lingkungan kampus yang telah memiliki dan yang belum memiliki instrumen yuridis berupa peraturan rektor atau surat keputusan rektor, atau surat edaran rektor tentang pengelolaan dan penanggulangan sampah di lingkungan kampus. 2) kebersihan lingkungan kampus yang telah memiliki dan yang belum memiliki sarana dan prasaran penunjang sesuai Keputusan Menteri Kesehatan Republik Indonesia Nomor 1405/MENKES/SK/XI/2002 tentang syarat kesehatan Lingkungan Kerja Perkantoran dan Industri.

\section{B. METODE PENELITIAN}

Metode yang digunakan adalah yuridis empiris yang berfungsi untuk melihat hukum dalam artian nyata dan meneliti bagaimana bekerjanya hukum di lingkungan masyarakat.[6] Penedekatan penelitian yang digunakan adalah sosiologis. Subyek Penelitian terdiri dari responden dan informen. Responden adalah seseorang atau individu yang akan memberikan respon terhadap pertanyaan yang diajukan oleh peneliti, sedangkan informan adalah orang atau individu yang memberikan informasi terkait data yang dibutuhkan oleh peneliti sebatas yang diketahuinya.

Jenis Data dan Bahan Hukum: 1) Data primer adalah jenis data yang diperoleh langsung dari lapangan. 2) Data sekunder adalah data yang diperoleh langsung dari kepustakaan atau literatur atau bahan pustaka yang berkaitan dengan masalah atau materi penelitian.[7] Bahan Hukum: adalah bahan yang diperoleh dari kajian hukum.[6] Bahan hukum dibagi menjadi tiga yaitu sbagai berikut: 1)Bahan hukum primer yaitu bahan hukum yang dapat dilihat sebagai data yang merupakan perilaku hukum dari warga 2)Bahan hukum sekunder yaitu bahan hukum yang berasal dari kepustakaan, 3)Bahan 
hukum tersier adalah bahan hukum yang dapat memberikan penjelasan terhadap bahan hukum primer yang dapat berupa rancangan perundangundangan, hasil penelitian, buku-buku teks dan berita internet.[7]

Metode Pengumpulan Data dalam penelitian menggunakan dua yaitu pertama, metode wawancara adalah sebuah dialog yang dilakukan oleh pewawancara.[8] Pendapat lain mengatakan bahwa metode wawancara adalah suatu teknik pengumpulan data yang dilakukan dengan cara tanya jawab antara penanya atau pewawancara dengan nara sumber. Kedua, metode dokumentasi yaitu metode untuk menemukan data mengenai hal-hal atau variabel berupa dokumentasi, serta menjadikan pencatatan sistematis.

Metode analisis data merupakan kegiatan dalam penelitian yang berupa melakukan kajian atau telaah terhadap hasil pengolahan data yang dibantu dengan teori-teori yang telah didapat sebelumnya,[7] yaitu: 1) Deskriptif, peneliti dalam menganalisis berkeinginan untuk memberikan gambaran atau pemaparan atas subjek dan objek penelitian sebagaimana hasil penelitian yang dilakukanya. 2) Evaluatif, peneliti memberikan justifikasi atas hasil penelitian. Peneliti akan memberikan penilaian dari hasil penelitian, apakah hipotesis dari teori hukum yang diajukan diterima atau ditolak. 3) Perspektif, analisis dimaksudkan oleh peneliti untuk memberikan argumentasi atas hasil penelitian yang telah dilakukan.

\section{HASIL DAN PEMBAHASAN}

\section{Peran Rektor dalam Program Zero Waste di Lingkungan Kampus di Kota Mataram}

Peran rektor dalam program zero waste di lingkungan kampus di kota Mataram belum maksimal. Asumsi tersebut terbangun berdasarkan hasil penelitian sebagai berikut: 1) Masih banyaknya perguruan tinggi (universitas) di kota Mataram kondisi kebersihan lingkungan kampusnya belum zero waste 2) Masih banyak perguruan tinggi (universitas) di kota Mataram yang belum memiliki instrumen yuridis (peraturan rektor atau surat keputusan rektor atau surat edaran rektor) tentang sistem pengelolaan dan penanggulangan sampah di lingkungan kampus. 3) Masih banyak perguruan tinggi (universitas) di kota Mataram yang belum menerapkan standar syarat kesehatan Lingkungan Kerja Perkantoran dan Industri berdasarkan Keputusan Menteri Kesehatan Republik Indonesia Nomor 1405/MENKES/SK/XI/2002.

Fakta diatas menunjukkan lemahnya peran rektor dalam mewujudkan program zero waste dalam lingkungan kampus di Kota Mataram. Idealnya rektor harus berperan aktif untuk merespon program tersebut melalui pengadaan instrumen yuridis dalam bentuk (peraturan rektor atau surat keputusan rektor, atau surat edaran rektor) tentang tentang sistem pengelolaan dan penanggulangan sampah di lingkungan kampus. Selain itu rektor harus pula mengupayakan ketersediaan sarana dan prasana penunjang kebersihan sesuai Keputusan Menteri Kesehatan Republik Indonesia Nomor 1405/MENKES/SK/XI/2002 tentang standar syarat kesehatan Lingkungan Kerja Perkantoran dan Industri.

Keputusan Menteri Kesehatan Republik Indonesia Nomor 1405/MENKES/SK/XI/2002 tentang standar syarat kesehatan Lingkungan Kerja Perkantoran dan Industri, persyaratan pengeloaan dan penanggulangan limbah padat/sampah adalah a. Setiap perkantoran harus dilengkapi dengan tempat sampah dari bahan yang kuat, cukup ringan, tahan karat, kedap air dan mempunyai permukaan yang halus pada bagian dalamnya serta dilengkapi dengan penutup. b. Sampah kering dan sampah basah ditampung dalam tempat sampah yang terpisah. c. Tersedia tempat pengumpulan sampah sementara yang memenuhi syarat. Standard ini baru diterapkan disebagian kecil perguruan tinggi (universitas) di Kota Mataram. Fakta ini membuktikan bahwa peran rektor belum maksimal dalam program zero waste dilingkungan kampus di Kota Mataram.

Barometer untuk menentukan maksimal atau tidaknya peran rektor dalam program zero waste di lingkungan kampus di Kota Mataram diukur berdasarkan 3 (tiga) standard yaitu: 1) Kondisi kebersihan lingkungan kampus. 2) Ketersediaan instrumen yuridis tentang sistem pengelolaan dan penanggulangan sampah di internal perguruan tinggi, 3) Ketersediaan sarana dan prasarana penunjang sesuai standar Keputusan Menteri Kesehatan Republik Indonesia Nomor 1405/MENKES/SK/XI/2002 tentang standar syarat kesehatan Lingkungan Kerja Perkantoran dan Industri.

Penelitian dilakukan di 5 (lima) universitas di Kota Mataram: Universitas Mataram, Universitas Al-Azhar Mataram, Universitas Muhammadiyah Mataram, Universitas 45 Mataram, Universitas Nahdatul Wathan Mataram. Penentuan pilihan universitas sebagai sample penelitian berdasarkan beberapa alasan: 1) universitas dipimpin oleh rektor sehingga sesuai dengan fokus kajian yang ingin melihat maksimalitas peran rektor dalam program zero waste dilingkungan kampus. 2) Universitas terdiri dari banyak fakultas dan banyak program studi, sehingga keterpilihannya sudah dianggap mewakili institusi perguruan tinggi di wilayah Kota Mataram. Penelitan ini dilaksanakan pada bulan Agustus tahun 2018.

Tabel 1

Program Zero Waste di Lingkungan Kampus

\begin{tabular}{|c|c|c|c|c|c|}
\hline No & PT & Informan & $\begin{array}{l}\text { Kondi } \\
\text { si } \\
\text { kamp } \\
\text { us }\end{array}$ & Sapras & $\begin{array}{l}\text { Pera } \\
\text { n } \\
\text { Rekt } \\
\text { or }\end{array}$ \\
\hline 1 & Univer & Dr. & Zero & Surat & Maksi \\
\hline
\end{tabular}




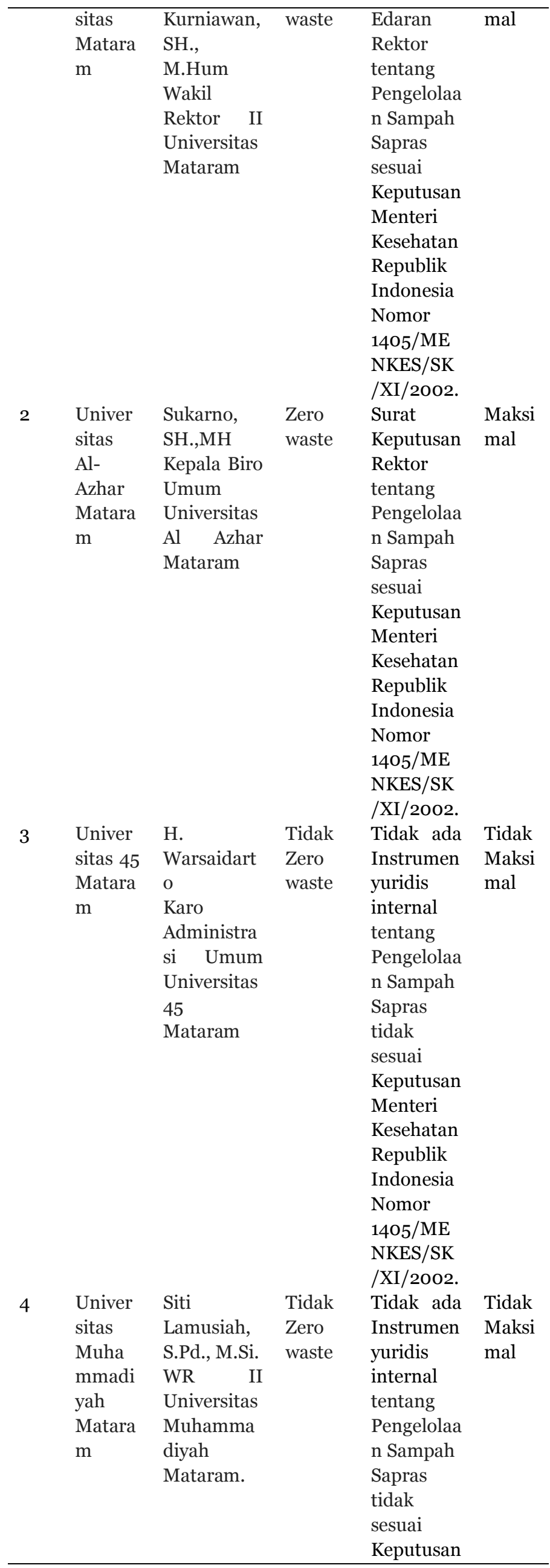

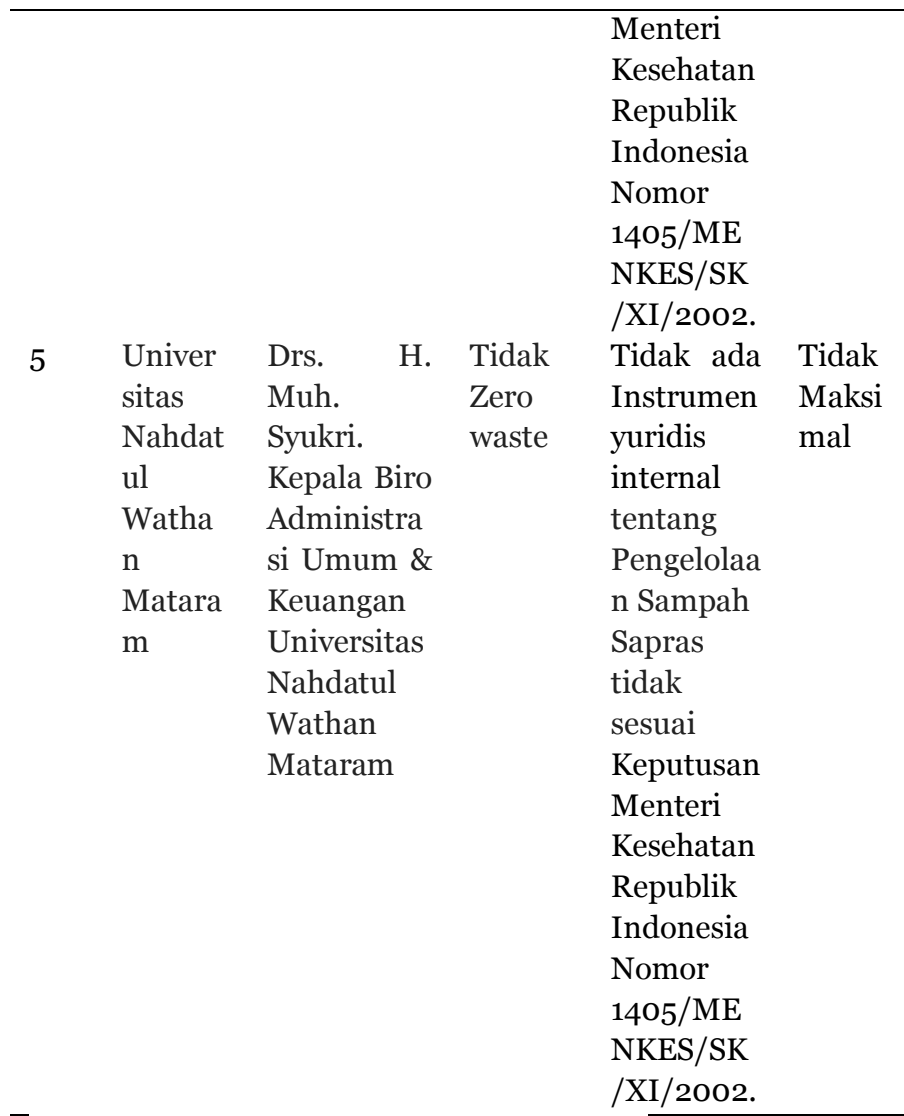

Data hasil penelitan bulan Agustus 2018

\section{Grafik 1}

Perbandingan Peran Rektor Dalam Program Zero Waste di Kota Mataram

\section{Persentase Kriteria Pengelolaan Kampus}

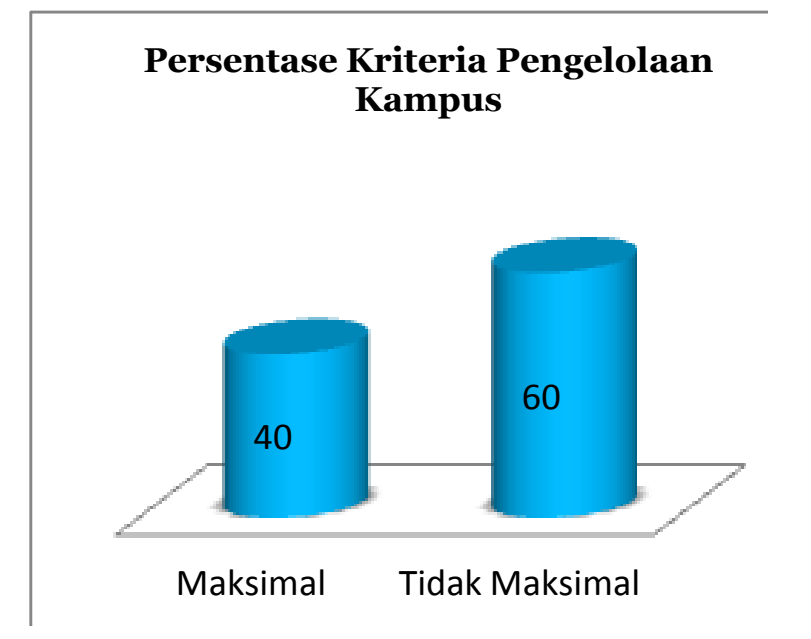

Hasil penelitian diatas menunjukkan bahwa masih banyak rektor di kota Mataram yang belum berperan maksimal dalam program zero waste di lingkungan kampusnya. Dari 5 (lima) perguruan tinggi (universitas) yang dijadikan sample penelitian hanya ada 2 (dua) pimpinan perguruan tinggi (rektor) yang telah melaksanakan perannya secara maksimal dalam program zero waste di lingkungan kampusnya. Maksimalitas peran rektor dalam program zero waste di implementasikan melalui: 1) ketersediaan instrumen yuridis dalam bentuk peraturan rektor, atau surat 
edaran rektor, atau surat keputusan rektor tentang sistem pengelolaan dan penanggulangan sampah di lingkungan kampus. 2) ketersediaan sarana dan prasana penunjang di lingkungan kampus yang sesuai dengan Keputusan Menteri Kesehatan Republik Indonesia Nomor 1405/MENKES/SK/XI/2002 tentang standar syarat kesehatan Lingkungan Kerja Perkantoran dan Industri.

Tiga universitas sample penelitian ditemukan kondisi kebersihan lingkungan kampusnya tidak zero waste. Kondisi ini terjadi karena :1) tidak tersedianya instrumen yuridis dalam bentuk peraturan rektor, atau surat edaran rektor, atau surat keputusan rektor tentang sistem pengelolaan dan penanggulangan sampah di lingkungan kampus. 2) tidak tersedianya sarana dan prasana penunjang di lingkungan kampus yang sesuai dengan Keputusan Menteri Kesehatan Republik Indonesia Nomor 1405/MENKES/SK/XI/2002 tentang standar syarat kesehatan Lingkungan Kerja Perkantoran dan Industri.

\section{Upaya Efektif Penanggulangan Masalah Sampah dalam Lingkungan Kampus}

Kompleksitas permasalahan sampah di lingkungan kampus semakin sulit terurai. Kondisi ini dipicu oleh perilaku civitas akademika yang tidak sportif membuang sampah.[9] Perilaku merupakan hasil atau respon atas stimulus atau dorongan terhadap diri seseorang. Perilaku tersebut terdiri atas tiga bentuk, yaitu koginitf, afektif, dan psikomotor. Kognitif adalah perilaku yang berdasarkan pola pikir seseorang. Afektif adalah perilaku yang tercermin dari sikapnya sehari-hari. Psikomotorik merupakan perilaku yang berdasarkan pada tindakan.[10] Inspotifitas membuang sampah masuk dalam kriteria prilaku Afektif. Prilaku infortifitas dalam hal membuang sampah juga terjadi dalam lingkungan kampus, terbawa oleh civitas akademika. Himbauan dan slogan tentang kebersihan yang sudah diterapkan di lingkungan kampus ternyata belum berhasil memutus mata rantai insportifitas civitas akademika. Prilaku tersebut sangat bertolak belakang dengan hakekat peran dan fungsi kampus sebagai sarana estafet ilmu pengetahuan bukan hanya dalam perspektif teori melainkan juga dalam praktek yang diaktualisasikan melalui sikap dan prilaku seluruh civitas akademika.

Inspotifitas yang terjadi dalam lingkungan kampus akan berdampak fatal apabila dibiarkan bergulir tanpa solusi. Untuk memutus mata rantai perilaku tersebut dapat dilakukan melalui strategi strategi efektif. Dalam konteks teori strategi merubah prilaku dapat dilakukan melalui beberapa metode seperti: 1) Inforcement adalah strategi perubahan dilakukan dengan cara paksaan dengan menggunakan peraturan atau perundang-undangan yang diberlakukan. 2) Education adalah strategi perubahan perilaku dilakukan dengan pemberian pengajaran, informasi, atau penyuluhan.[10] Strategi inforcement nampaknya lebih tepat dan cepat sebagai solusi dalam masalah ini, mengingat kegagalan dari strategi education yang telah dilakukan melalui sosialisasi, himbauan dan lain sebagainya namun belum berhasil. Untuk merubah perilaku insportifitas harus dilakukan dengan cara paksaan melalui peraturan atau perundang-undangan atau instrumen yuridis dalam bentuk peraturan rektor atau surat edaran rektor, atau surat keputusan rektor. Efektifitas instrumen yuridis terhadap spotifitas civitas akademika dalam hal membuang sampah dilingkungan kampus dapat dilihat dalam dilihat dalam tabel berikut:

\section{Tabel 2}

Perbandingan Kondisi Kampus Yang memiliki dan Tidak Memiliki Instrumen Yuridis Tentang Sistem Pengelolaan dan Penanggulangan sampah

\begin{tabular}{|c|c|c|}
\hline $\begin{array}{c}\text { Nama Perguruan } \\
\text { Tinggi }\end{array}$ & $\begin{array}{l}\text { Ketersediaan } \\
\text { Instrumen } \\
\text { Yuridis }\end{array}$ & $\begin{array}{l}\text { Kondisi } \\
\text { Kampus }\end{array}$ \\
\hline Universitas Mataram & Ada & Zero waste \\
\hline $\begin{array}{l}\text { Universitas } \\
\text { Mataram }\end{array}$ & Tidak ada & Tidak zero waste \\
\hline $\begin{array}{l}\text { Universitas } \\
\text { Muhammadiyah } \\
\text { Mataram }\end{array}$ & Tidak ada & Tidak zero waste \\
\hline $\begin{array}{l}\text { Universitas Al Azhar } \\
\text { Mataram }\end{array}$ & Ada & Zero waste \\
\hline $\begin{array}{l}\text { Universitas Nahdatul } \\
\text { Wathan Mataram }\end{array}$ & Tidak ada & Tidak zero waste \\
\hline
\end{tabular}

-Data hasil penelitan bulan Agustus 2018

Hasil penelitian diatas menjadi barometer penulis untuk menawarkan strategi efektif pengelolaan sampah dalam lingkungan kampus yaitu dengan pengadaan instrumen yuridis berupa peraturan/keputusan rektor. Strategi ini menjadi upaya preventif sekaligus refresif dalam hal penanggulangan sampah yang nantinya mampu mewujudkan kampus bersih dan zero waste. Kampus adalah bagian dari proses penyelenggaraan Negara dalam bidang pendidikan. Sebagai penganut konsep negara hukum, maka kampuspun harus tunduk pada koridor bernegara untuk mengaktualisasikan asas legalitas dalam internal kampus, sehingga penyelenggaraan program kampuspun harus dikawal dengan instrument hukum yang jelas. Menurut Ten Berge, asas legalitas adalah pembatasan kebebasan warga negara oleh pemerintah harus ditemukan dasarnya dalam undang-undang yang merupakan peraturan umum. Undang-undang secara umum harus memberikan jaminan terhadap (warga negara) dari tindakan (pemerintah) yang sewenang-wenang, kolusi dan berbagai jenis tindakan yang tidak benar. Pelaksanaan wewenang oleh pemerintah harus dapat ditemukan dasarnya pada undang-undang tertulis (undang-undang formal). Tujuan hukum itu untuk mewujudkan kebaikan. Ariestoteles menyatakan bahwa 
untuk mencapai kehidupan yang paling baik (the best life posibble) dapat dicapai dengan supremasi hukum.[11] Prinsip ini juga berlaku dalam segala aspek penyelenggaraan negara tidak terkecuali dalam dunia akademis.

Format managerial pengeloaan kampus juga tidak jauh berbeda dengan managerial penyelenggaraan negara, hanya ruang lingkup dan spesifikasi bidang yang dikelola yang berbeda. Dalam struktur organisasi tata kelola kampus, rektor berperan sebagai pemegang kewenangan tertinggi dalam penyelenggaraan aktifitas tata kelola kampus, baik internal maupun eksternal. Bagir Manan mendefinisikan wewenang dalam bahasa hukum tidak sama dengan kekuasaan (mach). Kekuasaan hanya menggambarkan hak untuk berbuat dan tidak berbuat, sedangkan wewenang sekaligus berarti hak dan kewajiban (rechten en plichten).[11]

Untuk mengawal segala proses tata kelola tersebut dibutuhkan instrumen yuridis yang dijadikan sebagai payung hukum dan juga sarana kontrol agar tujuan dan target yang diharapkan dapat terwujud sesuai harapan. Secara umum instrumen hukum dalam organisasi kampus diatur secara berjenjang dan hirarkis yang disesuaikan dengan kebutuhan. Instrumen hukum tertinggi tentu tidak terlepas dari aturan yang bersifat umum yaitu undang-undang tentang Sisdiknas, undang undang tentang Perguruan Tinggi, Kepmenristek Dikti. Secara khusus setiap kampus memiliki instrumen yuridis seperti Statuta, Peraturan Rektor, Surat Keputusan Rektor, Surat Edaran Rektor, dan aturan lainnya sampai ketingkat fakultas. Instrumen yuridis yang bersifat hirarkis tersebut tidak boleh saling bertentangan. Dalam penerapannya harus tunduk pada keberlakuan asas hukum seperti Lex Specialis Derogat Legi Generali (ketentuan peraturan yang bersifat khusus mengenyampingkan ketentuan yang bersifat umum, Lex Superiori Derogat Legi Inferiori (ketentuan peraturan yang mempunyai derajat lebih tinggi didahulukan pemanfaatannya/penyebutannya daripada ketentuan yang mempunyai derajat lebih rendah).

Rektor sebagai pengendali tertinggi aktifitas tata kelola kampus memiliki kewenangan yang luas dalam rangka menggiring segala program kampus baik itu merupakan beakdown dari aturan yang bersifat umum maupun aturan internal kampus. Dalam praktek rektor sering tidak menggunakan secara maksimal kewenangannya untuk berperan aktif dalam merespon instrumen yuridis yang bersifat umum kedalam instrumen yuridis khusus di lingkungan perguruan tinggi yang dipimpinnya. Hal ini penting dilakukan mengingat instrumen yuridis yang bersifat umum muatan isi atau substansinya tidak mengatur secara rinci, sehingga harus ditindaklanjuti dengan instrumen yuridis yang lebih rinci disesuaikan dengan kebutuhan masing masing perguruan tinggi.
Program tata kelola kampus harus dikawal dengan instrumen yuridis agar dalam pelaksanaanya tidak terjadi pelencengan. Kampus merupakan sarana transfer ilmu yang efektif, bukan hanya dalam tataran teori melainkan juga dalam kontek doktrinasi paradigma dan prilaku bagi civitas akademika, seperti dalam upaya menamkan pola hidup bersih dan sportifitas membuang sampah dalam lingkungan kampus. Namun dalam tataran implentasi perilaku sportif tersebut sulit terwujud. Untuk merubah perilaku bukanlah hal muda, namun bukan tidak mungkin untuk dirubah. Secara psikologis upaya untuk merubah prilaku atau kebiasaan dapat dilakukan dengan beberapa cara seperti: menciptakan alasan, ganti dengan kebiasaan lain, memutus siklus mata rantai penyebab yang salah satunya dengan kondisi lingkungan. Lingkungan adalah segala sesuatu yang ada di sekitar individu, baik lingkungan fisik, biologis, maupun sosial. Lingkungan berpengaruh untuk mengubah sifat dan perilaku individu karena lingkungan itu dapat merupakan lawan atau tantangan bagi individu untuk mengatasinya.

Proses perubahan perilaku pada hakekatnya sama dengan proses belajar. Proses perubahan perilaku tersebut menggambarkan proses belajar pada individu yang terdiri dari:[12] 1) Stimulus (rangsang) yang diberikan pada organisme dapat diterima atau ditolak. Apabila stimulus tersebut tidak diterima atau ditolak berarti stimulus itu tidak efektif mempengaruhi perhatian individu dan berhenti disini. Tetapi bila stimulus diterima oleh organisme berarti ada perhatian dari individu dan stimulus tersebut efektif. 2) Apabila stimulus telah mendapat perhatian dari organisme (diterima) maka ia mengerti stimulus ini dan dilanjutkan kepada proses berikutnya. Setelah itu organisme mengolah stimulus tersebut sehingga terjadi kesediaan untuk bertindak demi stimulus yang telah diterimanya (bersikap). 3) Akhirnya dengan dukungan fasilitas serta dorongan dari lingkungan maka stimulus tersebut mempunyai efek tindakan dari individu tersebut (perubahan perilaku). Untuk merubah prilaku dibutuhkan strategi khusus sebagai wujud upaya preventif dan represif. Preventif adalah suatu tindakan pengendalian sosial yang dilakukan untuk mencegah atau mengurangi kemungkinan terjadinya hal-hal yang tidak diinginkan di masa mendatang. Represif adalah suatu tindakan pengendalian sosial yang dilakukan setelah terjadinya suatu pelanggaran atau peristiwa buruk. Dengan kata lain tindakan dilakukan setelah peristiwa terjadi misalnya pelanggaran. Kedua upaya ini bisa dielaborasi dalam satu strategi efektif berbentuk instrumen hukum. Kehadiran instrumen hukum mempertegas bahwa segala tindakan pemerintahan harus didasarkan pada peraturan perundang-undangan yang sah dan tertulis sebagai aktualisasi asas legalitas (due process of law).[6][13][14] Peraturan perundangundangan tertulis tersebut harus ada dan berlaku lebih 
dulu atau mendahului tindakan atau perbuatan administrasi yang dilakukan. Keberadaanya instrumen hukum yang mendahului suatu perbuatan administrasi merupakan wujud konkrit upaya preventif untuk mengantisipasi kemungkinan kemungkinan terhadap pelanggaran.

Strategi untuk mencapai suatu target tujuan hukum disebut politik hukum. Sudarto berpendapat bahwa politik hukum adalah usaha untuk mewujudkan peraturan-peraturan yang baik sesuai dengan keadaan dan situasi pada suatu saat dan kebijakan dari negara melalui badan-badan yang berwenang untuk menetapkan peraturan-peraturan yang dikehendaki yang diperkirakan bisa digunakan untuk mengekspresikan apa yang terkandung dalam masyarakat dan untuk mencapai tujuan yang dicitakan. Kolektivitas muatan isi hukum merupakan cerminan petunjuk yang harus ditaati. Ketaatan masyarakat dalam berhukum tidak sama sehingga secara substantif suatu ketentuan hukum perlu mengakomulasi ketentuan tentang sanksi bagi pelanggar.[15][16][17] Klausul sanksi merupakan upaya refresif sebagai wujud ganjaran terhadap pelanggaran yang sudah terjadi. Sanksi dalam suatu aturan hanyalah strategi doktrinasi awal agar masyarakat mentaati hukum, namun ketaatan yang menjadi cita hukum adalah ketaatan yang lahir dari kesadaran mendalam sebagai wujud elaborasi pemikiran yang rasional dan transendental.

Berbagai problem persampahan di lingkungan kampus sebagaimana diuraikan diatas merupakan suatu phenomena rumit yang perlu solusi penanganan cepat dan tepat. Problem ini berawal dari adanya kesenjangan dan inkonsistensi terkait penangannya persampahan dalam bentuk instrumen yuridis tentang sistem pengelolaan dan penaggulangan sampah. Secara Nasional pemerintah telah menetapkan aturan sebagaimana diatur dalam UU No 18 Tahun 2008 tentang Penanggulangan Sampah. Pemerintah Provinsi Nusa Tenggara Barat juga telah meresponnya dengan Peraturan Daerah Provinsi Nusa Tenggara Barat Nomor 5 Tahun 2019 Tentang Pengelolaan Sampah. Instrumen yuridis yang bersifat umum perlu di breakdown kedalam instrumen yuridis yang bersifat khusus untuk diberlakukan dalam internal masing masing perguruan tinggi seperti peraturan rektor, atau keputusan rektor, dan atau surat edaran rektor.

\section{SIMPULAN DAN SARAN}

Peran rektor dalam program zero waste dilingkungan kampus di Kota Mataram belum maksimal. Penyebab lingkungan kampus tidak zero waste karena dua hal: 1) ketidaktersediaan instrumen yuridis dalam bentuk (peraturan rektor atau surat keputusan rektor, atau surat edaran rektor) tentang tentang sistem pengelolaan dan penanggulangan sampah di lingkungan kampus. 2) Ketidaktersediaan sarana dan prasana penunjang kebersihan sesuai Keputusan Menteri
Kesehatan Republik Indonesia Nomor 1405/MENKES/SK/XI/2002 tentang standar syarat kesehatan Lingkungan Kerja Perkantoran dan Industri.

Berdasarkan kesimpulan di atas, peneliti merekomendasikan saran. kepada pimpinan perguruan tinggi (rektor) untuk memaksimalkan perannya dalam program zero waste melalui pengadaan instrumen yuridis tentang sistem pengelolaan dan penanggulangan sampah di lingkungan kampus dan pengadaan sarana dan prasana penunjang kebersihan sesuai Keputusan Menteri Kesehatan Republik Indonesia Nomor 1405/MENKES/SK/XI/2002 tentang standar syarat kesehatan Lingkungan Kerja Perkantoran dan Industri

\section{UCAPAN TERIMA KASIH}

Penulis mengucapkan terima kasih kepada editor yang senantiasa memberikan saran dan masukan kepada penulis sehingga artikel ilmiah bisa terselesaikan.

\section{DAFTAR RUJUKAN}

[1] I. W. Widiarti, "Pengelolaan Sampah Berbasis Zero Waste Skala Rumah Tangga Secara Mandiri," J. Sains Teknol. Lingkung., vol. 4, no. 2, pp. 101-113, 2012.

[2] H. A. Andary, "Analisis Pengolahan Sampah Berbasis Zero Waste sebagai Salah Satu Upaya Universitas Semarang (USM) mewujudkan EcoCampus," Teknika, vol. 12, no. 1, pp. 6-15, 2017.

[3] C. Rahmawati, B. L. Nopitasari, S. M. WD, A. K. Wardani, and B. Nurbaety, "Penyuluhan pengelolaan sampah plastik menuju' zero waste kampus ummat," SELAPARANG J. Pengabdi. Masy. Berkemajuan, vol. 3, no. 2, pp. 196-198, 2020.

[4] D. M. R. Fernando, "What is Zero Waste?"

[5] T. Intan and S. R. Wardiani, "Kampanye Zero Waste Sebagai Gaya Hidup Pada Mahasiswa Dan Ibu Rumah Tangga Di Jatinangor (Analisis Situasional Dan Rencana Solusi)," J. DAYA-MAS, vol. 4, no. 1, pp. 5-13, 2019.

[6] P. Mahmud Marzuki, "Penelitian Hukum," Jakarta: Kencana Prenada Media, 2015.

[7] M. Fajar and Y. Achmad, "Dualisme penelitian hukum normatif dan empiris," Yogyakarta: Pustaka Pelajar, 2010.

[8] A. Suharsimi, "Prosedur Suatu Pendekatan Praktek," Jakarta PT. Rineka Cipta, 2006.

[9] S. Notoatmojo, "Pengantar pendidikan dan perilaku kesehatan dan ilmu perilaku kesehatan," Jakarta Andi Offset, 1993.

[10] T. H. Handoko and B. Swasta, "Perilaku Konsumen," Yogyakarta BPFE, 2008.

[11] H. R. Ridwan, Hukum administrasi negara. RajaGrafindo Persada, 2006.

[12] L. J. Hofland and S. W. J. Lamberts, "The pathophysiological consequences of somatostatin receptor internalization and resistance," Endocr. 
126 CIVICUS : Pendidikan-Penelitian-Pengabdian Pendidikan Pancasila dan Kewarganegaraan | Vol. 8, No. 2, September 2020, hal 119-2020

Rev., vol. 24, no. 1, pp. 28-47, 2003.

[13] M. Siahaan, "Peran Mahkamah Konstitusi dalam Penegakan Hukum Konstitusi,” J. Huk. Ius Quia Iustum, vol. 16, no. 3, pp. 357-378, 2009.

[14] Z. A. Fakrulloh, "Penegakan Hukum Sebagai Peluang Menciptakan Keadilan,” 2005.

[15] Moeljatno, Azas-asas Hukum Pidana. Seksi Hukum Pidana Fakultas Hakum Universitas Gadjah Mada, 1969.

[16] K. Prayitno, "restorative justice untuk peradilan di Indonesia (perspektif yuridis filosofis dalam penegakan hukum In concreto)," J. Din. Huk., vol. 12, no. 3, pp. 407-420, 2012.

[17] S. Akhmaddhian, "Penegakan Hukum Lingkungan dan Pengaruhnya Terhadap Pertumbuhan Ekonomi di Indonesia (Studi Kebakaran Hutan Tahun 2015)," UNIFIKASI $J$. Ilmu Huk., vol. 3, no. 1, 2016. 